\title{
A New Edition of the Poems of Marina Tsvetaeva ${ }^{1}$
}

he literary fate of Marina Tsvetaeva, who in my view is one of the
most remarkable Russian poets of the twentieth century, took its ultimate shape sadly and instructively. The highest point of Tsvetaeva's popularity and reputation during her lifetime came approximately between 1922 and 1926, i.e., during her first years in emigration. Having left Russia, Tsvetaeva found the opportunity to print a whole series of collections of poetry, narrative poems, poetic dramas, and fairy tales that she had written between 1916 and 1921: Mileposts 1 (Versty 1), Craft (Remeslo), Psyche (Psikheia), Separation (Razluka), Tsar-Maiden (Tsar'-Devitsa), The End of Casanova (Konets Kazanovy), and others. These books came out in Moscow and in Berlin, and individual poems by Tsvetaeva were published in both Soviet and émigré publications. As a mature poet Tsvetaeva appeared before both Soviet and émigré readership instantly at her full stature; her juvenile collections Evening Album (Vechernii al'bom) and The Magic Lantern (Volshebnyi fonar') were by that time forgotten. Her success with readers and critics alike was huge and genuine. If one peruses émigré journals and newspapers from the beginning of the 1920s, one is easily convinced of the popularity of Marina Tsvetaeva's poetry at that period. Her writings appeared in the Russian journals of both Prague and Paris; her arrival in Paris and appearance in February 1925 before an overflowing audience for a reading of her works was a literary event. Soviet critics similarly published serious and sympathetic reviews.

But later, the situation began to change. By that time, Contemporary Annals (Sovremennye zapiski) and Prague's Will of Russia (Volia Rossii) had published Tsvetaeva's recollections of the days of the October Revolution and the Civil War: "Free Passage" ("Vol'nyi proezd"), "My Jobs" ("Moi sluzhby"), and "October Revolution in a Railroad Car" ("Oktiabr' v vagone"). These sketches, which gave a vivid and merciless picture of the

1 Translated by Joan Grossman. Originally published as "Novoe izdanie stikhov Mariny Tsvetaevoi” in Novyi zhurnal, no. 84 (1966): 295-300. 
epoch, aroused the wrath of orthodox Soviet criticism. With their publication began the Soviet press's hostile attitude toward Tsvetaeva's work, which in the 1930s changed to total silence. A negative attitude toward Tsvetaeva among émigré critics began at about the same time, though it was provoked by entirely different reasons.

By the time they appeared, those works that particularly pleased the émigré critics-Verses to Blok (Stikhi $k$ Bloku), the play Fortuna-belonged for the poet herself to a phase already past. After her emigration, Tsvetaeva's talent underwent a profound and rapid evolution. By the middle of the 1920s she had reached her mature writing manner, having assimilated the best achievements of styles attempted earlier: the highly excited Romanticism of her early poetry collections and "Romantic" plays; stylization in the manner of folk laments, underworld jingles similar to limericks, sentimental "cruel" ballads, and other folklore genres in the collection Mileposts 1 and, in part, in Craft (and of course in her folktales); and finally, high-style Church-Slavic lexicon and Tsvetaeva's extremely individual version of the Russian Baroque. In her new manner Tsvetaeva wrote some highly original and profound pieces: Poem of the End (Poema Kontsa), The Stairs (Lestnitsa), The Pied Piper (Krysolov), tragedies based on stories from Greek mythology, and the collection After Russia (Posle Rossii). These appear to us now, well after the poet's death, to be the summit of Tsvetaeva's creative work, her most precious contribution to the development of Russian poetry in the twentieth century.

Tsvetaeva's contemporaries thought otherwise. With all the variety of aesthetic positions of writers of the older generation of that time, the unanimity with which Maksim Gorky (in letters to Pasternak), Ivan Bunin, and Zinaida Gippius, all failing to understand Tsvetaeva's mature writings, paid them scant attention or wrote of them with obvious disdain, is striking. In Tsvetaeva's complex style of the 1920s, many émigré critics saw empty wordplay, unmotivated virtuosity, ostentatious "originality," and hysteria, where now we who approach her work with good will and attention see brilliant and genuine verbal power, superb mastery of verse form, spiritual depth, and expressive transmission of delicate psychological nuances.

In the 1930s Tsvetaeva's reputation began to wane. In the Soviet Union only rarely was she mentioned, and then with contempt and unvarying references to her "White counterrevolutionary sympathies" and "reactionary" position. For the older émigré writers Tsvetaeva was linked with constant attention to the verbal side of poetry and artistic prose, which 
was unacceptable to them. (In a way they were right-Tsvetaeva's mastery oversteps the boundaries of schools and trends and, as one of the outstanding instances of Russian "verbalism" of the twentieth century, she is the literary ally of Bely, Remizov, Mayakovsky, and Pasternak.) For the younger Paris poets and critics of the 1930s, Tsvetaeva as poet was, it might be said, rather too brilliant, vivid, and life-loving. The Paris school was attracted rather to despair, weariness, murmurs, little peculiarities of speech-that same murmuring that Tsvetaeva earlier, already in 1921, had rejected:

Not for these flattering garments, deceitful cassocks-

Vociferous was I born to this world!

My dreams are not nocturnal-[they're] in broad daylight!

Unlike you, I don't live by hissing, whispering!

(Не для льстивых этих риз, лживых ряс-

Голосистою на свет родилась!

Не ночные мои сны-наяву!

Шипом-шопотом, как вы, не живу!).

Of course, there were critics in the emigration who wrote of Tsvetaeva warmly and with understanding: Marc Slonim, Yury Ivask, Alfred Bem, and, by the thirties, Vladislav Khodasevich (who earlier had written of her with reserve or negatively). In the émigré press two articles appeared about Tsvetaeva by Prince Dmitry Svyatopolk-Mirsky (on The Swain [Mólodets] and on The Pied Piper) - until now in general the best criticism written about Tsvetaeva. But in the 1930s the tone in émigré criticism was dominated by the Paris school—and the great poet Marina Tsvetaeva in the last years of her life abroad remained, in her own words, "without readers and without criticism."

The Second World War and the end of the 1940s were a time when Tsvetaeva was almost forgotten. After her suicide in Elabuga, unmentioned by the Soviet press, her name totally disappeared from Soviet books, newspapers, and even encyclopedias. In the emigration only Georgy Fedotov in 1942 proclaimed Tsvetaeva "the number one Russian poet of our era."

2 Fedotov's statement is from his "On Parisian Poetry" (first published in Kovcheg: Sbornik russkoi zarubezhnoi literatury [The ark: A collection of Russian literature abroad], compiled by V. F. Mansvetov [New York, 1942]). 
He was an exception. Much more typical in the 1940s were the constant attacks and slurs on Tsvetaeva by Georgy Adamovich and Nikolai Otsup. It was typical that even Tsvetaeva's correspondent Aleksandr Bakhrakh, in his obituary (which appeared in the Paris-based Russian Miscellany [Russkii sbornik] and was the sole public notice of her death), felt it necessary to underline her "mannered style," her "failures and blunders." He also proclaimed Psyche and Craft to be her finest collections, leaving unmentioned her greatest works, written and published after 1921.

But Tsvetaeva's oblivion lasted a relatively short time. The Thaw set in, and Tsvetaeva was remembered in her homeland and almost simultaneously (what caused this constant and surprising parallel?) in the emigration. In the 1950s, Tsvetaeva emerged before a new generation of readers who had not heard of her-in the memoirs of Ilya Erenburg, in the "Autobiographical Sketch" of Boris Pasternak (so far unpublished in the Soviet Union, but translated into many languages), and in her own works, which in the Soviet Union have been gradually reprinted and republished since 1956.

At the same time there appeared abroad a collection of her prose, her volume of verse about the civil war called The Demesne of the Swans (Lebedinyi stan), and letters to Bakhrakh, Ivask, Roman Goul, Fedotov, and Anatoly Steiger. All this revealed to the reader some completely new, unknown features of Tsvetaeva's literary and personal image. From around 1960 one encounters more and more rarely in the émigré press complaints about Tsvetaeva's "spoiled" talent, her "incomprehensibility" and "hysteria"-which were so common in the 1930s and 1940s. Certain critics (for example, Vladimir Weidlé) who at one time wrote rarely and negatively of Tsvetaeva now treat her work with attention and respect.

In 1961 the one-volume collection of selected lyrics that had been promised in 1956 appeared in the Soviet Union. Despite a certain tendentious selection of material that narrowed and limited the general image of Tsvetaeva's poetry, that volume, which sold out in Moscow in two days, actually revealed to the Soviet reader the range and variety of that poetry. ${ }^{3}$ Now, in much-expanded form, this volume has been republished in the series "Poet's Library" (Moscow/Leningrad, 1965), edited by Tsvetaeva's

3 Marina Tsvetaeva, Izbrannoe, ed. V. Orlov (Moscow: Gos. izd-vo khudozhestvennoi literatury, 1961). 
daughter Ariadna Efron and Anna Saakyants, with an introductory article by Vladimir Orlov (an expanded, augmented and corrected version of his introduction to the 1961 volume). ${ }^{4}$ The book contains not only lyrics, but also narrative poems and dramatic works by Tsvetaeva.

Along with Poem of the End and Poem of the Hill (Poema Gory), which became known to Soviet readers in the 1961 volume, it includes the fairy tale narrative in verse Tsar-Maiden, the lyrical satire The Pied Piper, Poem of the Staircase (originally printed in Freedom of Russia under the title "The Staircase"), the tragedy Ariadna, and other major pieces by Tsvetaeva that were almost unknown to readers abroad and were completely new to Soviet readers. Immense labor was expended in collecting poems of Tsvetaeva that had appeared in rare émigré publications. Fifty-five poems, unpublished but preserved in the archive of Tsvetaeva's daughter, are printed here for the first time. All the same, despite the wealth of material represented in the volume, one is struck by the omission of many significant poems and cycles. This is not a matter of differing tastes or disagreement among the compilers about the significance of one or another of Tsvetaeva's pieces. The rehabilitated Tsvetaeva, previously accused of "White" sympathies and reactionary leanings, now was subject to an effort at refashioning her image in official Soviet style and transforming her, after the fact, into a stereotype of Soviet respectability. It was difficult, of course, to expect that a volume published in the Soviet Union would contain verses from The Demesne of the Swans, which praised the White movement, or the splendid counterrevolutionary poems "Riotous Carnival!" (“Maslenitsa shiroka!") and "Like Migrants to Some New York?" ("Pereselentsami- / V kakoi N'iu-Iork?") from Craft. But also excluded were Tsvetaeva's relatively few, but significant, religious lyrics (for example, the profound and original "God" ("Bog") from After Russia). Deliberately omitted from her most important collection, After Russia, were poems expressing Tsvetaeva's peculiar Platonic idealism, her striving for "other worlds"- such poems as "The Blindly Flowing Sobbing of Lethe" ("Lety slepotekushchii vskhlip") or "Sybilla to the Infant" ("Sivilla-mladentsu"). (True, the selection does include the splendid "The Train" ("Poezd"), where these "Platonic" motives are interwoven with domestic-social criticism.) Finally, also omitted

4 Marina Tsvetaeva, Izbrannye proizvedeniia, introd. by V. Orlov, ed. A. Efron and A. Saakiants (Moscow/Leningrad, 1965). 
from the volume was the high point of Tsvetaeva's patriotic lyric, her stunning cycle on the death of Mayakovsky (with the superb description of the meeting of the two suicides Mayakovsky and Esenin in the Kingdom of Heaven). In Orlov's foreword this cycle is referred to as a "contradictory piece," in which "some false notes are heard." Moreover, the cycle is represented by a tendentious choice of excerpts. In this manner, Tsvetaeva as poet is presented to the Soviet reader incompletely.

Along with the tendentious selection of works, it must be noted that two major pieces included in the volume suffered cuts by the censor. In the first instance this refers to The Pied Piper. In form the largest of Tsvetaeva's works, this poem at the time of its appearance called forth the ecstatic responses of Pasternak and Fedotov and the extremely interesting article by Svyatopolk-Mirsky. However, the work passed unnoticed by the majority of émigré critics (though Mikhail Osorgin, in a well-meaning piece about the "romantic" Tsvetaeva, called The Pied Piper a "very musical piece of nonsense").

The Pied Piper is a work exceptional for its genre: satire, as indicated in the subtitle, actually is interwoven with lyric and even philosophy in an original, fantastic blend. In the poem, keen satire is directed against bourgeois stupidity and malice in all its guises-including the Soviet variety. This is underlined by the fact that the rats from which the hero frees the town of Hamelin speak in quasi-Communist jargon (they have not only glavkhvost and glavshish [common disrespectful nicknames for superiors], but also their own rat version of NEP [New Economic Policy]). In an effort to restrict the poem's meaning to a satirical portrayal of German bourgeoisie, the editors actually maimed The Pied Piper. In the notes it is said that this poem is printed "with insignificant omissions." In fact, from the third chapter 134 lines are eliminated. The fourth chapter is treated almost as ruthlessly, since the passages cut are essential for understanding Tsvetaeva's idea, and their absence leads to a distorted understanding of the entire poem. From Poem of the Staircase (Poema Lestnitsy) a quatrain containing an ironic parallel of Marx and the devil is omitted.

Yet despite the cuts and misquotes in the book's commentaries (for example, in the notes to the poem "The Naiad" ("Naiada"), p. 755, there is attributed to Tsvetaeva-who, at the end of the 1920s was writing about the White defenders of Perekop-the glorification of their Red opponents), and despite the necessity of reducing Tsvetaeva's complex and inimitable 
worldview, in the foreword and notes, to the usual Soviet formulae, the publication of Selected Works of Marina Tsvetaeva is a great and joyous event for those who value Russian poetry. In the Soviet Union at the present time, Tsvetaeva is one of the most loved and most sympathetic poets, especially among the young literary generation. In her originality, her freedom from any dogma, her profound contemporariness, and her genuine ethical purity, young Russians see not only poetry, but also, as many foreign visitors report, a valuable lesson about life. This recognition and reevaluation, of which Pasternak wrote, are already, to a degree, occurring. But to print Tsvetaeva's creative work in full, in all its variety and independence, is at present impossible in the Soviet Union. It would be good if émigré publishers would fill this gap and reprint Tsvetaeva's "forbidden" works: first of all, the complete Pied Piper, then Perekop, The Red Bull-Calf (Krasnyi bychok), the cycles on the death of Voloshin (Ici-Haut) and the death of Mayakovsky, the drama on the French Revolution, Fortuna, and the interesting cycle of reminiscences of the epoch of the Civil War.

SK was perfectly placed to evaluate the two Soviet editions (1961 and 1965) of the works of Marina Tsvetaeva, once he had completed the revision of his PhD dissertation, which was published within a few short months of this review (Simon Karlinsky, Marina Cvetaeva: Her Life and Art [Berkeley: University of California Press, 1966]). This pioneering work made him, as it were, the godfather of a burgeoning field of study and the instigator of intense interest in the oeuvre of Tsvetaeva. He eventually determined that the vast amount of new information which had come to light in the intervening twenty years necessitated a new look at his subject, and wrote Marina Tsvetaeva: The Woman, Her World, and Her Poetry (Cambridge: Cambridge University Press, 1986). In the meanwhile, he had published a number of reviews and essays in Russian on her life and work, and for this volume we have translated four of them, since the material they contain is treated cursorily if at all in his two Englishlanguage, book-length studies of the poet.

The review translated here also comprises a remarkably succinct but comprehensive introduction to Tsvetaeva. Again, we have chosen here and below to supply transliterated Russian titles of the poet's writings for the use of readers who can consult the original texts. 